\title{
Kent Peyzajında Işık ve Renk Üzerine Kullanıcı Değerlendirmeleri: Samsun Kenti Örneği
}

\author{
Yeliz ŞAHIN ${ }^{1}$ (D) , Ömer ATABEYOĞLU 2*(D) \\ ORCID 1: 0000-0002-2681-6302 \\ ORCID 2: 0000-0001-7230-8598 \\ ${ }^{1}$ Ordu Üniversitesi, Fen Bilimleri Enstitüsü, Peyzaj Mimarlığı Ana Bilim Dalı, 52200, Ordu, Türkiye. \\ ${ }^{2}$ Ordu Üniversitesi, Ziraat Fakültesi, Peyzaj Mimarlığı Bölümü, 52200, Ordu, Türkiye. \\ *e-mail: omeratabeyoglu@odu.edu.tr
}

Öz

Mimari ifadeyi güçlendirip kentsel algıyı artırarak tasarımcının, mekân kullanıcısı veya kentli üzerinde doğru etkiyi oluşturmada iki öğe Işık ve renktir. Bu öğeler aracılığıyla mekâna ilişkin güvenlik, duygu, beğeni, talep, fonksiyonellik gibi pek çok olgu da kontrol edilebilir. Bu bakış açısı ile çalışma, Samsun kenti örneğinde kurgulanmıştır. Çalışmanın amacı, Samsun kenti örneğinde tasarımda ışık ve rengin etkisini ortaya koymak, kentli gözünden ışık ve rengin mekân algısını tespit etmektir. Çalışma, litearür incelemesi, veri toplama, analiz, değerlendirme bütününde gerçekleştirilmiştir. Bu kapsamda, kent halkına anket uygulanmıştır. Anket ile kentsel alanlarda ışık ve renk kullanımına ilişkin değerlendirme, beklenti ve tercihler tespit edilmiştir. Tasarımda ışık ve renk algııının insanlar üzerindeki etkisi de anket ile belirlenmistir. Ankete göre kullanıcılar, kentsel tasarımda renk kullanımı ve çevre ilişkisini önemsemektedir. Ayrıca, kentsel fonskiyonların kullanımını kolaylaştıracak düzeyde aydınlatma beklentisine sahiplerdir. Kentli, bir kenti canlı ve renkli kılmakta bina cepheleri, donatılar ve bitkilerin doğru ve uyumlu renkler ile kullanımın etkili olacağında hem fikirdir. Bununla birlikte; kentsel öğelerde doğru renk tercihleri, uygun aydınlatma seçenekleri ve etkin projelendirme canlı ve dinamik bir kent oluşturmakta etki yaratacaktır.

Anahtar Kelimeler: Görsel algı, insan psikolojisi, kentsel tasarım, mekân algısı, anket

\section{User Ratings on Light and Color in The Urban Landscape: The Case of Samsun City}

\begin{abstract}
Light and color are two elements in creating the right effect on the designer, the user of the space or the citizen by strengthening the architectural expression and increasing the urban perception. Many phenomena such as security, emotion, taste, demand, functionality can be controlled through these elements. With this point of view, the study was designed in the example of the city of Samsun. The aim of the study is to reveal the effect of light and color in design in the example of the city of Samsun, and to determine the perception of light and color from the eyes of the city dweller. The study was carried out in the context of literature review, data collection, analysis and evaluation. In this context, a questionnaire was applied to the people of the city. With the questionnaire, evaluations, expectations and preferences regarding the use of light and color in urban areas were determined. The effect of light and color perception on people in design was also determined by a survey. According to the survey, users care about the relationship between the use of color and the environment in urban design. In addition, they have a lighting expectation that will facilitate the use of urban functions. Urban residents agree that the use of building facades, equipment and plants with correct and harmonious colors will be effective in making a city lively and colorful. With this; Correct color preferences, suitable lighting options and effective project planning in urban elements will have an impact on creating a lively and dynamic city.
\end{abstract}

Keywords: Visual perception, human psychology, urban design, space perception, survey

Citation/Atıf: Şahin, Y. and Atabeyoğlu, Ö. (2022). Kent peyzajında ışık ve renk üzerine kullanıcı değerlendirmeleri: Samsun Kenti örneği. Journal of Architectural Sciences and Applications, 6 (2), 676-687.

DOI: https://doi.org/10.30785/mbud.987736 


\section{Giriş}

İnsanlar arasındaki etkileşim çevre tarafından önemli ölçüde etkilenir. Öyle ki çevre, bu etkileşimi geliştirebilir veya koparabilir. Dahası, bulunulan çevre o çevredeki insanların ruh halleri ve davranışları üzerine de doğrudan etkilidir (Christoffersen, 2011). Bununla birlikte, insanlar kendilerine fiziksel ve ruhsal açıdan iyi gelen mekanları tercih ederler. Bu nedenle de yapılı çevrede uyumlu ve olumlu psikolojik etkilere sahip tasarımların önemi büyüktür (Ganslandt ve Hofman, 1992; Philips, 2000). Erzen'e (2006) göre; insan çevresini algılayıp, etki yarattığı için çevrenin bir parçasına dönüşür. Bu nedenle de çevre, tüm bileşenleriyle aktif bir şekilde ilişki kurulabilen bir olgudur. Fizik mekânı yani çevreyi oluşturan bileşenler renk, ses, koku, ışık, nem, titreşim ve hava sirkülasyonu gibi insan üzerinde doğrudan etkili parçaların bütünüdür. Işık ve renk ise en etkili iki parçadır (Sirel, 1997). Yaşam alanlarında kullanılan renk ve ışık, insan için uygun standartların sağlanmasında son derece önemlidir. Mekânda kullanılan renkler ve ışık bireylerin ruh hali üzerine de etkilidir (Küller ve Mikellides, 1993).

Mekân ve nesnenin algılanmasını sağlayan ışık miktarı ve yoğunluğu üç faktör tarafından etkilenir; renk, doku ve yüzey. Böylece göz, aldığı veriyle görme ve tanıma görevini yerine getirir. Ayrıca nesnelerin parlaklığı, bulundukları alanın parlaklığına ve kontrast etkilere bağlılık gösterir (Kolb, 2003). Uluslararası Aydınlatma Komisyonu aydınlatmayı; "nesneler ve çevrelerinin görülebilmesi" olarak tanımlar. Bu açıdan bakıldığında aydınlatmanın bir amacı ve fonksiyonu, bunun yanında ise estetik ve mimari bir yönü olması gerekir (Fitoz, Küçükerman ve Esen, 2007). Işık, nesnelerin ve bunların etrafının daha iyi görülebilmesi ve algılanabilmesi için uygulanır (Sirel, 1997). Ancak aydınlatma, aynı zamanda mimarinin dördüncü boyutudur. Hassas bir şekilde entegre olan kaliteli aydınlatma, iç veya dış ortamın ruhunu taşır. Kaliteli bir aydınlatma tasarımı, havayı ayarlar, alanı güçlendirir ve güvenlik ve enerji tasarrufu gibi özel intiyaçlara ulaşır. Kaliteli tasarım, aydınlatma tasarımında belirtilen tüm hedeflere ulaşmak için önemli bir zaman ve özen gerektirir (Christoffersen, 2011).

Işık nedeniyle aynı fiziksel ortamda farklı atmosferleri algılamak mümkündür. Işık, mekanların tasarımı için temel bir ilgi alanı oluşturmakta ve bu nedenle peyzaj mimarisinde kalite tartışmasında önemli bir rol oynamaktadır (Fontenelle, 2008). Mekansal ışık, insanların ruhsal durumlarını önemli ölçüde etkiler. Aynı zamanda farklı ışık karakterleri insan davranışlarını yönlendirebilmektedir. Özellikle mimaride ışığın doğru kullanımları insan psikolojisi ve estetik algı açısından önemli kazanımlar sağlar. Schulz (1984), "Yerin Ruhu" kitabında çevredeki ışığın, içinde bulunulan mekâna ait hissedilebilmesini sağladığını söyler. Bunun da mitolojik kökenlerinin olduğunu ifade eder. Rasmussen, (1964) ise, ışığın geldiği yönün önemli olduğunu, bunun mekânda yaratılan etkiyi değiştirdiğini ve bu etkinin mekân veya nesnenin özelliklerinin iyi belirlenmesi ile oluşturulabileceğini söyler.

Işık gibi renk de sadece doğa değil insan yapımı çevrenin önemli ve vaz geçilemez bir parçasıdır (Radwan, 2015). Insan bedeninin yönelim, hızlanma, yavaşlama gibi tepkileri renklerle ilişkilidir. Danger (1987), farklı bireylerin aynı renklere verdikleri psikolojik tepkilerin benzeştiğini savunur. Kandinsky'e (1993) göre; renk de duygular gibi derinleşip gelişerek yaşantıya dönüşebilir. Bu açıdan değerlendirildiğinde ruhsal duyarlıık ile renk etkisi arasında derin bir ilişki vardır. Duyarlılık düzeyi düştükçe rengin etkisi de zayıflar, duyarlıık yükseldikçe rengin etkisi de daha derin gerçekleşir. Öte yandan Janssens'e (2000) göre, renkten kaynaklı olarak ruh hali ile performans arasında bir etkileşim mevcuttur. Dahası, renkler sayesinde toplumun sosyal ve psikolojik yapısı hakkında çıkarımlarda bulunulabilmektedir. Renkler farklı birey ve toplumların özelliklerine göre tasarım sürecinde kullanılır. Çünkü renk tasarım talebinde bulunan kişi ve toplumların dünyası ve ruhunun bir ürünüdür (Özdemir, 2005).

Mekân algısı, ışık ve rengin mekanla bütünleşme biçimiyle ilişkilidir. Peyzaj mimarlığıyla ilgili olarak, mekân algısı renkle, malzemeyle veya mekânın kendisiyle ilgili olabilir, ancak mekân algısı esasen hem nesneyi hem de gözlemciyi içeren aydınlatma durumuna bağlıdır (Fontenelle, 2008). Dedeoğlu (2006) ve Bostancı'ya (2004) göre gün ışığının yaşam alanlarına yetmediği zaman ve bölgelerde orada yaşayan bireylerin güvende hissetmesi, yönlerini bulabilmesi, şehirlerin geceleri de gündüz olduğu 
gibi güvenli ve aktif kalması, yaşam alanlarının estetik açıdan çekici kılınması, açık hava aktivitelerinin düzenlenmesi, kent kimliği inşası gibi nedenler aydınlatmanın motivasyonlarındandır.

İster kentsel alanlar ister kapalı mekanlarda olsun aydınlatmanın insan üzerindeki olumlu etkileri büyüktür. Öyle ki hem doğal hem de yapay olarak parlak ışığa sahip odalar depresyon, ajitasyon ve uyku gibi sağılı sorunlarını iyileştirebilmektedir (Christoffersen, 2011). Ayrıca aydınlatma, kişilerin biyolojik ritmi ve sirkadyen döngüsü uyku-uyanıklık düzeni, yeme düzeni, duygu durumu gibi birçok önemli sağlık bileşenini de etkilemektedir (Akıncı ve Orhan, 2016). Jones'a (1989) göre ise; aydınlatma ışı̆̆ın teknik kısmı nedeniyle bilim, duygulara hitap etmesi nedeniyle de sanattır.

Kentsel aydınlatma yaşam kalitesinin artırılması açısından kentsel planlamanın önemli bir ögesidir. Kentsel aydınlatmada, kentin gece görünümü ön plana çıkar. Bu sebeple, kentin gece kullanım amacı da önem arz eder. Kentsel aydınlatma, güvenlik, emniyet, yönlendirme, reklam, manzara, kimlik, girişim, sosyal etkileşim gibi faydalarının yanı sıra kentlerde çekiciliğin sağlanması için kullanılmaktadır (Şerefhanoğlu, 2005).

Kentsel aydınlatmanın en önemli görevi estetik boyutundan da öte geceleri kentlerde emniyeti sağlamasıdır (Onuk, 2008). Benzer şekilde kent meydanlarının vurgulanabilmesi ve çekici bir özellik taşıması yeterli ışık alması ile mümkündür (Arifoğlu, 1999). Işığın geliş yönü de aydınlatmanın etkisi değiştirilerek algıya etki eder (Ünver, 2001).

Çok yüksek parlaklığa sahip renklerde dikkatin toplanma süresi uzayabilir ve dikkat süresi kısalabilir. Düşük doygunluk ve parlaklığın kullanıldığı ortamlarda birey çevreden çok içedönük bir ruh haline bürünmekte ve kendisi ile zaman geçirmektedir. Bu sebeple zihinsel görevlerin daha yoğun olduğu ortamlarda düşük doygunluk ve parlaklıktaki renkler tercih edilmektedir (Başoğlu, 2007).

Danger (1987), farklı bireylerin aynı renklere verdikleri psikolojik tepkilerin benzeştiğini savunmaktadır. Kwallek ve ark., 'a (1996) göre ise, renk doygunluğu erkekler ve kadınlar arasında ruh halindeki farklııkların belirgin bir yordayıcısıdır. Bir alanın renklerinin o alandaki bireylerin psikolojik ruh halini etkileyebileceğine dair de pek çok kanıt vardır (Kuller ve Mikellides, 1993).

Bu doğrultuda çalışmada da amaç, Samsun kenti örneğinde gerçekleştirilen anketten yola çıkarak; ışık ve renk olgusunu peyzaj mimarlığı bakış açısı ile değerlendirmektir. Aynı zamanda, kentlilerin gözünden kente ilişkin ışık ve renk farkındalığı ve değerlendirmeleri ile genel olarak ışık ve renk olgusu hakkındaki tercihlerini tespit etmektir.

\section{Materyal ve Yöntem}

Çalışmanın birincil materyalini Samsun kenti ve kentlileri oluşturmaktadır. İkincil materyalini ise veri toplamak amacıyla gerçekleştirilen anket formu oluşturmaktadır. Ankette, toplam 33 soru bulunmaktadır. Sorular kuramsal temellere uygun olarak oluşturulmuştur. Form dört bölüme sahiptir. Formda yer alan ilk 6 soru demografik özellikleri, ikinci bölümdeki 8 soru renk tercihleri, üçüncü bölümdeki 9 soru ışık ile ilgili tercihleri, dördüncü bölümdeki 10 soru ise Samsun ile ilgili görüşleri belirleme amacıyla sorulmuştur.

Anket çalışmasının evreni, 640.000 kişiden oluşmaktadır. Ankete binde bir örneklem yöntemiyle toplam 600 kişi katıımıştır. Ankete katılanlar, çalışmada katılımcı olarak ifade edilmiştir.

Çalışma, litearür incelemesi-veri toplama-analiz-değerlendirme yöntemi temelinde geliştirilmiştir. Bu bağlamda çalışma; literatürün incelenmesi, Samsun kentine ilişkin aydınlatma özellikleri ve etkisinin incelenmesi, literatür temelinde anket sorularının hazırlanması, anket çalışmasının uygulanması, bulguların analizi, sonuç ve önerilerin geliştirilmesi sürecinde yürütülmüştür. Katılımcılar rastgele seçim yöntemiyle seçilmiştir.

Anket 2019 tarihlerinde, yaklaşık 3 ayda sürede gerçekleştirilmiştir. Anket yüz-yüze görüşme tekniği ile uygulanmıştır. Elde edilen veriler istatistiki olarak değerlendirilmiştir. İstatistiki analizler için SPSS 16 yazılımı kullanılmıştır. Anket verileri, frekans ve ki-kare analizleri ile değerlendirilmiştir. 


\section{Bulgular ve Tartışma}

\subsection{Bulgular}

\subsubsection{Katılımcıların demografik özellikleri}

Ankete katılanların \%45,3'ü erkek, \%54,7'si kadındır. Anket değişik yaş gruplarındaki kişilerle yapılmıştır. Katılımcıların \%8,3'ünün $18^{\prime}$ den küçük, \%46,3'ünün 18-30, \%38,3'ünün 31-60 ve \%7'sinin 60 yaştan büyük olduğu belirlenmiştir. Bireylerin kültür seviyeleri ile renk ve aydınlatma tercihleri de değişmektedir. Ankete katılan farklı eğitim düzeyindeki kişilerin renk ve aydınlatma isteklerinin tespit edilebilmesi için öncelik olarak eğitim durumları tespit edilmiştir. Ankete katılanların \%1,3'üu ilkokul, \%3,2'si ortaokul, \%40,7'si lise, \%50,2'si üniversite, \%4,7'si ise lisansüstü mezunudur.

Farklı meslek grubundaki kişilerin renk ve aydınlatma konusundaki düşüncelerinin de değişiklik gösterebileceği düşünüldüğünden anket farklı meslek gruplarına uygulanmıştır. Ankete katılanların \%14'ü işçi, \%24,7'si memur, \%2'si çiftçi, \%4,7'si esnaf, \%14'ü serbest meslek, \%40'ının ise çalışmadığı tespit edilmiştir. Ankete katılanların oturdukları semt aydınlatma ve renk konusunda oldukça önemlidir. Buna göre; katılımcıların dağılımı şehir merkezi \%32,7, illkadım \%30,2, Atakum \%22,3, Canik \%8,8, Tekkeköy \%6 şeklindedir.

\subsubsection{Katılımcıların renk ve aydınlatma hakkındaki görüşleri}

Peyzaj tasarım çalışmalarında ana kriter kullanıcıdır. Tasarımda renk etkisini ortaya koyabilmek için rengin bireyler üzerindeki etkisini öğrenmek önemlidir. Bu amaçla; "Hayatınızda rengin sizin üzerinizde olumlu etkisi var mıdır?” sorusu sorulmuştur. Buna göre $\% 93,17$ evet, $\% 6,83$ hayır cevabını vermiştir. Bireylerin renklere yüklediği anlam, demografik veriler ve entelektüel düzeye göre (kültür, yaş ve cinsiyet gibi) etkenlerle değişiklik göstermektedir. Mevsimsel değişimlerin insanların psikolojilerinde nasıl bir etki bıraktığını, renk ile ilgili düşüncelerini etkileyip etkilemediğini anlamak amacıyla ankette bazı renklerin insanlara ne hissettirdiği de sorulmuştur. Buna göre; yeşil renk insanlara \%78 huzur, \%8.33 sakinlik, \%6,67 özgürlük, \%2,5 enerji ve \%5,5 diğer duyguları hissettirmektedir. Sarı rengin insan psikolojisindeki yeri için katılımcılardan; \%35,5 enerji, \%39,3 neşe, $\% 2$ huzur, \%9 kaygı, \%4,5 yorgunluk, \%5,6 sakinlik, \%3,5 özgürlük hissettirdiği verisi toplanmıştır. Mavi renk katılımcılara; \%58 huzur, \%19,5 özgürlük, \%18,3 sakinlik, \%1,8 neşe, \%0,5 enerji, \%0,5 kaygı hissettirmiştir. Kırmızı renk; \%42,5 kızıınlık, \%32,5 enerji, \%20 kaygı, \%2,3 yorgunluk, \%1,3 neşe hissettirmiştir. Beyaz renk katılımcılara; \%50,8 özgürlük, \%23,5 sakinlik, \%11,8 huzur, \%5,5 yorgunluk, $\% 2,3$ neşe, \%3 kaygı hissettirmiştir. Turuncu renk \%50 enerji, \%23 neşe, \%10,5 sakinlik, \%6,6 özgürlük, \%3,8 kaygı, \%3 yorgunluk; mor renk \%33 enerji, \%19 neşe, \%16 kaygı, \%11 sakinlik, \%5,3 özgürlük, \%2,6 yorgunluk, \%0,5 huzur; pembe renk \%67 neşe, \%10,5 enerji, \%3 huzur, \%2,3 sakinlik, $\% 4,3$ yorgunluk, \%2,6 özgürlük, \%1,5 kaygı, \%1 kızgınlık hissettirmiştir. Siyah renk ise; \%55,3 kaygı, $\% 25$ yorgunluk, \%7 sakinlik, \%3 kızgınlık, \%2 enerji, \%2 huzur hissettirmiştir.

Ankette, "Belediyeler binanın dış yüzey malzeme ve rengini seçmeye yetkili olmalı mıdır?" sorusunu katılımcılar \%45,5 evet, \%55,5 hayır şeklinde cevaplamıştır. Bir başka soruda ankete katılanların \%60' yapı kitlelerinin birbirine yakın renkler, $\% 21$ 'i farklı renkler ve $\% 18^{\prime} i$ aynı renkler ile boyanmasını tercih ettiklerini belirtmiştir. Rekreasyonel alanlarda canlı-cansız materyaller arasında katılımcıların $\% 56$ 'sı kısmen bir uyum olması gerektiği, \%42'si tam uyum olması gerektiği ve \%1'i de uyum olması gerekmediği görüşünü belirtmiştir. Samsun'daki bitkilerde renk değişimi katılımcıların \%52'sine göre ilkbahar-yaz mevsiminde gerçekleşmektedir. Samsun kentindeki renk kullanımı ankete katılan kişilerin \%61'ine göre rastgeledir.

Kentlerde halka açık alanlardaki aydınlatma işlevsel amaçıı olduğu kadar estetik amaçlı da olmalıdır. Ankete katılanların \%79'u yeterli düzeyde aydınlatma, \%16'sı çok iyi aydınlatma, \%4,6'sı ise loş aydınlatma tercih ettiğini belirtmiştir. Katılımcılar, bir kentteki aydınlatmanın; $\% 48,6$ renkli, $\% 42,8$ ışıışıl, \%4,3 tek renk ve \%4,1 oranla bölgesel olması gerektiği görüşünü belirtmiştir. Katılımcılar Samsun kentindeki ışık kullanımını ise; \%51,8 yeterli bulurken, \%46,5 rastgele, \%1,6 profesyonelce olarak değerlendirmiştir. Anket verilerine göre Samsun kentindeki aydınlatmanın en yeterli olduğu yerler; $\% 44,5$ alış-veriş merkezi, \%24 meydanlar, \%21,8 ana caddeler, \%6,1 parklar, \%2 ise sahildir. Katılımcılar kendi semtlerindeki aydınlatmayı; \%65,8 rastgele, $\% 32,1^{\prime}$ i yeterli, $\% 2^{\prime}$ si ise profesyonelce 
yapıldığını belirtmiştir. Ankette, çevre tasarımı yapılmış alanlarda ışıklandırmanın yetersiz olmasının katılımcıları nasıl etkilediği ölçülmek istenmiştir. Çıkan oranlara göre; \%86,3'ü çok etkilendiğini, $\% 12,1^{\prime} i$ az etkilendiğini, \%1'i ise etkilenmediğini belirtmiştir. Dış mekânın aydınlatılması her kullanıcıda farklı etki uyandırır. "Bir ortamın aydınlatılması sizde nasıl bir etki uyandırır?" sorusu sorulmuştur. Buna göre; \%63'ü güvenli, \%10'u bakımlı, \%10'u hareketli, \%7'si davetkâr ve \%5'i ise eğlenceli bir etki uyandırdığını belirtmiştir. Katılımcılara "Hava karardıktan sonra yaya bölgelerini kullanıyor musunuz?" sorusu sorulmuş; \%95,5'i kullandığını, \%6,5’i ise kullanmadığını belirtmiştir. Katılımcılar, dış mekân aydınlatmasında; \%91 oranla farkıı renk kullanılması gerektiğini söylerken, \%6 ile kullanılmaması gerektiğini belirtmiştir. Ankette, Samsun kentinde gece-gündüz kent görüntüsü arasında fark olduğu belirlenmiştir. Buna göre; katılımcıların \%47'si gece daha etkileyici olduğunu, \%43'ü gündüz, \%9'u ise gece ve gündüzün farklı etkileyiciliğe sahip olduğunu belirtmiştir.

\subsubsection{Katılımcıların demografik özellikleri ve görüşleri arasındaki ilişki}

Çalışmada katılımcılara ilişkin demografik özelliklerin görüşlere etkisini ortaya koyabilmek amacıyla kikare analizi kullanılmıştır. Analiz sonuçları aşağıda verilmiştir.

\subsubsection{Katılımcı yaşı ve görüşleri}

Binaların dış yüzeyinin nasıl boyanacağına dair fikirleri sorulduğunda 18 yaş altı katılımcıların \%36'sının aynı rengi ve \%36'sının aynı rengin farklı tonlarını tercih ettiği görülmektedir. Buna karşın daha ileri yaş grupları genel olarak aynı rengin farklı tonlarını tercih etmektedir. Ki Kare test sonucuna bakıldığında yaş ve binaların dış yüzeyinin boyanmasına dair tercih bağımlı değişkenler olarak bulunmuştur $\left(x^{2}=22\right.$. 394a, $\left.d f=6, p=0.001\right)$.

Renk tercihi yaparken tüm yaş gruplarındaki çoğunluk sevdiği renkleri tercih etmekle birlikte çevreden, modadan ve genel kabullerden en az etkilenenlerin 60 yaş üzeri nüfus olduğu göze çarpmaktadır. Sevdiği renkleri seçenler \%92,9 ile 60 yaş üzeri, çevreden etkilenenler \%16 ile 18 yaş altı, modadan en çok etkilenen \%16,9 ile 18-30 yaş ve genel kabullerden en çok etkilenenler \%4,4 ile 31-60 yaş aralığıdır. Bu durum kuşaklararası farklar ve gelişim süreçleri ile tutarlıdır. Yaş ile renk tercihinin anlamlı bir ilişki içinde olduğu söylenebilir $\left(x^{2}=26.340 a, d f=9, p=0.002\right)$.

Ortamın aydınlatılmasının farklı yaş gruplarında nasıl bir his yarattığı sorulduğunda katılımcıların \%64'ünün "güvenli" yanıtını verdiği görülmüştür. Tüm yaş gruplarında bu yanıt en büyük yüzdelere sahiptir ve \%60'ın üzerinde seyretmektedir. En az tercih edilen yanıt ise \%0,7 ile "seçkin" yanıtıdır. "Bakımlı" yanıtını verenler \%15,9'luk bir oranla 31-0 yaş grubu, "davetkâr" yanıtını verenler \%11,6 ile 18-30 yaş grubu, "hareketli" yanıtını verenler \%16,7 ile 60 yaş üzeri, "eğlenceli" yanıtını verenler $\% 12,8$ ile 18 yaş altı, "seçkin" yanıtını verenler ise \%1,5 ile 18-30 yaş aralığıdır. Yaş ile aydınlatmanın yarattığı hissin anlamlı bir ilişki içinde olduğu söylenebilir $\left(x^{2}=41.085 a, d f=15, p=0.0001\right)$.

Halka açık aydınlatmanın nasıl olduğu konusunda katılımcıların çoğunluğu yeterince aydınlatma yapılmasının yeterli olduğunu düşünmektedir. Yaş ile aydınlatma oranının anlamlı bir iliş̧i içinde olduğu söylenebilir ( $\left.x^{2}=23.800 a, d f=6, p=0.0001\right)$.

Değişik yaş gruplarından katılımcılar alt gruplarda ve total popülasyonda \%90'ın üzerinde bir oranda aydınlatmada farklı renklerin kullanılması gerektiğini düşünmektedir. Yaş ile farklı renklerin kullanıımasına dair görüş arasında anlamlı bir ilişki olduğu söylenebilir $\left(x^{2}=9.574 a, d f=3, p=0.023\right)$.

Samsun'un aydınlatma düzeninde renk kullanımının nasıl olduğuna dair fikirleri sorulduğunda farklı yaş gruplarının ortak fikirlerinin aydınlatmanın rastgele yapıldığına yönelik olduğu görülmektedir. Buna karşın en az tercih edilen yanıt \%0,8 ile "profesyonelce" tercihi olmuştur. Yaş ile Samsun'un aydınlatılmasındaki renk kullanımına dair görüş arasında anlamlı bir ilişki olduğu söylenebilir $\left(x^{2}=\right.$ 13.092a, $\mathrm{df}=6, \mathrm{p}=0.042$ ). Bununla birlikte katılımcılar aydınlatmanın genel özelliklerini yeterli olarak değerlendirmektedir (\%51). Buna ek olarak yaş ile aydınlatmanın genel değerlendirmesine dair görüş arasında anlamlı bir ilişki olduğu söylenebilir $\left(x^{2}=17.237 a, d f=6, p=0.008\right)$.

\subsubsection{Katılımcı cinsiyeti ve görüşleri}

Katılımcıların \%93'ü yaya bölgelerini hava karardıktan sonra da kullanmakla birlikte erkeklerde bu oran yaklaşık \%95, kadınlarda ise \%91'dir. Bu durum toplumsal cinsiyet ile ilişkilendirilebilir. Cinsiyet 
ile yaya bölgelerini hava karardıktan sonra da kullanmak arasında istatistiksel açıdan anlamlı bir görüş bulunmaktadır $\left(\mathrm{x}^{2}=6.634 \mathrm{a}, \mathrm{df}=1, \mathrm{p}=0.010\right)$.

Kadınlar \%88'e erkekler \%96'ya yakın bir oranda aydınlatmada farklı renklerin kullanılması gerektiğini düşünmektedir. Toplam popülasyonda bu oran $\% 91,6$ 'dır. Cinsiyet ve aydınlatmada farklı renklerin kullanılması tercihi arasında istatistiksel açıdan anlamlı bir ilişki vardır $\left(x^{2}=8.344 a, d f=1, p=0.004\right)$.

Her iki cinsiyette de katılımcılar kentin gece ve gündüz görünümü arasında fark görmekle birlikte (\%88) bu iki değişken arasında anlamlı bir ilişki bulunmaktadır $\left(x^{2}=0.037 a, d f=1, p=0.848\right)$.

\subsubsection{Katılımcı medeni hali ve görüşleri}

Hem evli hem de bekâr katılımcıların çoğunluğu binaların dış cephesinin boyanmasında aynı renk tonunu tercih edeceğini belirtmiştir. Bu oran bekârlarda \%56 ve evlilerde \%64'tür. Medeni hal ile binaların dış yüzeyinin boyanmasındaki tercih arasında istatistiksel açıdan anlamlı bir ilişki bulunmaktadır $\left(x^{2}=27.701 a, d f=2, p=0.0001\right)$.

Rekreasyonel alanlarda canlı ve cansı materyaller arasında renk uyumu olması gerekliliğine dair görüşün medeni hal ile ilişkisine bakıldığında evlilerin \%47 oranında bu görüşe kesinlikle katıldığı ve bekârların \%71,4 oranında kesinlikle katılmadığı görülmüştür. Medeni hal ve canlı ve cansız materyaller arasında renk uyumu olması gerekliliğine dair görüş arasında istatistiksel açıdan anlamlı bir ilişki vardır $\left(x^{2}=7.970 a, d f=2, p=0.019\right)$.

Hem evli $(\% 81,3)$ hem de bekâr $(\% 77,2)$ katılımcılar renk tercihinde sevdiği renkleri önceliğe aldığını beyan etmiştir. Medeni hal ve renk tercihindeki öncelik arasında istatistiksel açıdan anlamlı bir ilişki vardır ( $\mathrm{x} 2=10.144 \mathrm{a}, \mathrm{df}=3, \mathrm{p}=0.017$ ). Farklı medeni durumlarda aydınlatmanın yarattığı his ortak bir şekilde "güvenli" olarak tanımlanmıştır. Oranlar alt gruplar ve total popülasyonda \%60'ın üzerindedir. Medeni hal ve aydınlatmanın yarattığı his arasında istatistiksel açıdan anlamlı bir ilişki vardır $\left(x^{2}=\right.$ 15.218a, $d f=5, p=0.009$ ).

Bir kentteki aydınlatmanın nasıl olması gerektiğine dair görüşleri sorulduğunda katılımcıların genelinde \%49 ile renkli cevabı alınırken evlilerde en çok verilen cevabın \%51,3 ile renkli, bekârlarda ise \%49,8 ile ışıl ışı yanıtı olduğu görülmektedir. Medeni hal ile aydınlatmanın nasıl olması gerektiğine dair görüş arasında istatistiksel açıdan anlamlı bir ilişki bulunmaktadır $\left(x^{2}=13.237 a, d f=3, p=0.004\right)$.

Kentlerde halka açık alanlarında aydınlatmanın nasıl olması gerektiğine dair tercih sorgulandığında $\% 79,2$ ile en çok verilen yanıtın yeterince aydınlatılmış olduğu, alt gruplarda da benzeri bir görünümün olduğu ve oranların sırasıyla bekârlarda $\% 65,5$ ve evlilerde $\% 89,7$ olduğu bulunmuştur. Medeni hal ile halka açık alanlarında aydınlatmanın nasıl olması gerektiğine dair görüş arasında istatistiksel açıdan anlamlı bir ilişki bulunmaktadır $\left(x^{2}=52.187 a, d f=2, p=0.0001\right)$.

Katılımcılar hem genel olarak hem de alt gruplarda $\% 80$ 'in üzerindeki bir oranda aydınlatmada farklı renklerin kullanılması gerektiğini düşünmektedir. Medeni hal ve aydınlatmada farklı renklerin kullanılması arasında istatistiksel açıdan anlamlı bir ilişki bulunmaktadır $\left(x^{2}=20.234 a, d f=1\right.$, $p=0.0001)$. Katılımcılar \%60'ın üzerinde bir oranda kentin aydınlatılmasında renk kullanımının rastgele yapıldığını düşünmektedir. Bu oran alt gruplarda da total yüzdeye yakın seyretmektedir. Medeni hal ile kentin aydınlatılmasında renk kullanımının arasında istatistiksel açıdan anlamlı bir ilişki bulunmaktadır $\left(x^{2}=6,560 a, d f=2, p=0.038\right)$. Buna ek olarak katılımcılar aydınlatmanın genel özelliklerini yeterli bulmaktadır (\%51).

Medeni hallerin her ikisinde katılımcılar kentin gece ve gündüz görünümü arasında fark görmekle birlikte bu iki değişken arasında anlamlı bir ilişki bulunmaktadır $\left(x^{2}=8.229 a, d f=1, p=0.004\right)$.

\subsubsection{Katılımcı öğrenim durumu ve görüşleri}

Öğrenim durumuna göre bakıldığında toplam popülasyonun \%60’ı binaların dış yüzeyini aynı rengin farklı tonlarına boyamayı tercih etmekle birlikte bu görüşün alt gruplardaki tek istinası ilkokul mezunlarıdır. Illkokul mezunlarının \%75'i binaların dış yüzeylerinin farklı renklerde boyanmasını tercih etmektedir. Öğrenim durumu ve binaların dış yüzeylerinin boyanmasındaki renk tercihleri arasında anlamlı bir ilişki bulunmaktadır $\left(x^{2}=36.023 a, d f=8, p=0.0001\right)$. 
Rekreasyonel alanlarda canlı ve cansız materyaller arasında renk uyumu olması gerekliliğine dair görüşün öğrenim durumu ile ilişkisine bakıldığında tüm alt grupların $\% 40$ 'ın üzerinde görece farklılaşan oranlarda ve total popülasyonun \%56 oranında bu görüşe kısmen katıldığı görülmüştür. Öğrenim durumu ve canlı ve cansız materyaller arasında renk uyumu olması gerekliliğine dair görüş arasında istatistiksel açıdan anlamlı bir ilişki vardır $\left(x^{2}=46,036 a, d f=8, p=0.0001\right)$.

Tüm alt gruplar renk tercihinde sevdiği renkleri önceliğe almaktadır ve total popülasyonda bu oran $\% 77^{\prime}$ dir. Alt gruplarda da bu orana yakın seyretmektedir. Öğrenim durumu ve renk tercihi arasında renk uyumu olması gerekliliğine dair görüş arasında istatistiksel açıdan anlamlı bir ilişki vardır $\left(x^{2}=\right.$ 41.659a, $d f=12, p=0.0001$ ).

Kentin ışıklandırmasında kullanılan renklerin nasıl olması gerektiğine dair görüşlerin öğrenim durumuna göre farklılaşmasındaki dikkat çekici nokta genel popülasyonun \%48'i geçkin bir oranda renkli yanıtı vermişken, $\% 42,8^{\prime} i$, ışıl ışı yanıtını vermiştir. Bu yanıtın yoğunlaştığı alt gruplar ilkokul mezunları, ortaokul mezunları ve lisansüstü grubudur. Öğrenim durumu ve kentin aydınlatılmasında kullanılan renklerin nasıl olması gerektiğine dair görüş arasında anlamlı bir ilişki bulunmaktadır $\left({ }^{\times 2}=\right.$ 32.670a, $d f=12, p=0.001$ ).

Genel olarak şehrin aydınlatılmasının yeterince $(\% 79,2)$ olması gerektiği düşünülse de lisansüstü eğitim grubunda \%50'yi geçkin bir oranda çok iyi aydınlatılmış olması beklenmektedir. Öğrenim durumu ve kentin aydınlatılmasının nasıl olması gerektiğine dair görüş arasında anlamlı bir ilişki bulunmaktadır $\left(x^{2}=42.304 a, d f=8, p=0.001\right)$.

Katılımcıların \%94'ü hava karardıktan sonra yaya bölgelerini kullanmaktadır. Bu oran ilkokul mezunlarında yarı yarıya seyretmektedir. Öğrenim durumu ve hava karardıktan sonra yaya bölgelerinin kullanılması arasında anlamlı bir ilişki bulunmaktadır $\left(x^{2}=47.683 a, d f=4, p=0.001\right)$.

Genel olarak bakıldığında katılımcılar \%51,8 oranında aydınlatmanın genel olarak yeterli olduğunu düşünmektedir. Bu görüşe katılmayan tek eğitim grubu \%53,6 ile lisansüstüdür. Öğrenim durumu ve aydınlatmanın genel yeterliliği üzerine görüş arasında anlamlı bir ilişki bulunmaktadır $\left(x^{2}=34.252 a\right.$, $d f=8, p=0.001$ ).

Tüm eğitim seviyelerinden katılımcılar kentin gece ve gündüz görünümü arasında fark olduğunu düşünmektedir ve bu oran $\% 88^{\prime}$ dir. Öğrenim durumu ve kentin gece ve gündüz görünümü arasında fark olup olmadığına dair görüş arasında anlamlı bir ilişki bulunmaktadır ( $\left.x^{2}=12.910 a, d f=4, p=0.012\right)$.

\subsubsection{Katılımcı mesleği ve görüşleri}

Farklı meslek gruplarının binaların dış yüzeyinin nasıl boyanmasını tercih ettiklerine dair görüşlerine bakıldığında işçilerin \%41'lik bir oranda aynı rengi, kalan tüm meslek gruplarının (memur, çiftçi, esnaf, serbest meslek, çalışmayanlar) ve total popülasyonun aynı rengin farklı tonlarını tercih ettiği görülmektedir. Meslek ve binaların dış yüzeylerinin boyanmasındaki renk tercihleri arasında anlamlı bir ilişki bulunmaktadır $\left(x^{2}=52.049 a, d f=10, p=0.0001\right)$.

Rekreasyonel alanlarda canlı ve cansız materyaller arasında renk uyumu olması gerekliliğine dair görüşün meslek ile ilişkisine bakıldığında tüm alt grupların \%50'nin üzerinde ve genel popülasyonun $\% 56,1$ oranında bu görüşe kısmen katıldığı görülmektedir. Meslek ve canlı ve cansız materyaller arasında renk uyumu olması gerekliliğine dair görüş arasında istatistiksel açıdan anlamlı bir ilişki vardır $\left(x^{2}=32.362 a, d f=10, p=0.0001\right)$.

Genel popülasyon ve tüm alt gruplar renk tercihinde sevdiği renkleri ön plana almaktadır. Bu oran \%70'in üzerinde seyretmektedir. Meslek ve renk tercihindeki öncelik arasında istatistiksel açıdan anlamlı bir ilişki vardır $\left(x^{2}=32.662 a, d f=15, p=0.0005\right)$.

Farklı mesleklerden kişiler ortak görüş halinde aydınlatmanın onlarda yarattığı hissin "güvenli" olduğunu ifade etmiştir. Bu oran alt gruplarda en az esnaflarda \%54, en çok çiftçilerde \%75 ile çoğunluktadır. Meslek ve aydınlatmanın yarattığı his arasında istatistiksel açıdan anlamlı bir ilişki vardır $\left(x^{2}=46.621 a, d f=25, p=0.005\right)$. 
İşçilerin \%73,8'i kent aydınlatmasında renk kullanımının ışıl ışı olması gerektiğini düşünürken kalan meslek grupları ve toplam popülasyon $\% 48,7$ oranında renkli olması gerektiğini düşünmektedir. Meslek ve kentin aydınlatılmasında kullanılan renklerin nasıl olması gerektiğine dair görüş arasında anlamlı bir ilişki bulunmaktadır $\left(x^{2}=72.675 a, d f=15, p=0.0001\right)$.

Çiftçilerin tamamı, diğer meslek gruplarının \%60'ın üzerindeki oranı ve toplam katılımcıların \%79,2'si kentin yeterince aydınlatılması gerektiğini düşünmektedir. En az verilen yanıt ise \%4,7 ile loş aydınlatmanın gerekli olduğu düşüncesidir. Meslek ve kentin aydınlatılmasının renklerin nasıl olması gerektiğine dair görüş arasında anlamlı bir ilişki bulunmaktadır $\left(x^{2}=40.196 a, d f=16, p=0.0001\right)$.

Meslek gruplarının tamamı \%93,5'lik bir oran ile hava karardıktan sonra yaya bölgelerini kullanmaktadır. Alt gruplardaki yığılma da bu görüş ve orana yakındır. Meslek ve hava karardıktan sonra yaya bölgelerini kullanımı arasında anlamlı bir ilişki bulunmaktadır $\left(x^{2}=26.650 a, d f=5\right.$, $\mathrm{p}=0.0001$ ).

Mesleklerin büyük çoğunluğu en yüksek oran çiftçilerde \%100 ve en düşük oran \%82 ile işçilerde olmak üzere aydınlatmada farklı renklerin kullanılması tercihi bakımından olumlu görüş bildirmiştir. Meslek ve aydınlatmada farklı renklerin kullanılması tercihi arasında anlamlı bir ilişki bulunmaktadır $\left(x^{2}=14.146 a, d f=5, p=0.015\right)$.

Çiftçilerin \%67,7 oranında verdiği "yeterli" yanıtına karşın diğer meslek grupları ve total popülasyon $\% 61,8$ "lik bir genel yüzde ve alt grupların bu orana yakın seyreden yığılması ile kentin aydınlatılmasında renk kullanımının "rastgele" olduğunu düşünmektedir. Meslek ve kentin aydınlatılmasında renk kullanımına dair görüşler arasında anlamlı bir ilişki bulunmaktadır $\left(x^{2}=\right.$ 19.447a, $d f=10, p=0.035$ ). Buna karşın işçi ve memurların rastgele yanıtını vermesine karşın total popülasyon ve diğer meslek grupları \%51,8 oranında aydınlatmanın genel olarak yeterli olduğunu düşünmektedir. Meslek ve kentin aydınlatılmasına dair görüşler arasında anlamlı bir ilişki bulunmaktadır $\left(x^{2}=26.679 a, d f=10, p=0.003\right)$.

Meslek gruplarının tamamı \%80'in üzerinde bir oranda ve total popülasyon \%88 oranında kentin gece ve gündüz görünümü arasında fark olduğunu düşünmektedir. Meslek ve kentin gece ve gündüz görünümü arasındaki farka dair görüş arasında anlamlı bir ilişki bulunmaktadır $\left(x^{2}=21.304 a, d f=5\right.$, $\mathrm{p}=0.001)$.

\subsubsection{Katılımcının yaşadığı semt ve görüşleri}

Katılımcıların \%32,7'si şehir merkezinde, \%30,2'si İlkadım Mahallesi'nde, \%22,3'ü Atakum'da, \%8,8'i Canik'te, \%6'sı Tekkeköy'de oturmaktadır. Oturulan bölgeye göre binaların dış yüzeyini boyama tercihlerine bakıldığında alt grupların $\% 50$ 'sinden fazlasının ve genel popülasyonun $\% 60$ 'ının aynı rengin farklı tonlarına boyanmasını tercih ettiği görülmektedir. Oturulan mahalle ve bina dış yüzeylerinin boyanmasındaki renk tercihi arasında istatistiksel açıdan anlamlı bir ilişki mevcuttur $\left(x^{2}=\right.$ 19.362a, $d f=8, p=0.013$ ).

Katılımcıların geneli ve alt gruplardaki çoğunluk \%65'in üzerindeki bir oranda kentin genel aydınlatmasının rastgele olduğunu düşünmektedir. Oturulan mahalle ve aydınlatmaya dair genel görüş arasında istatistiksel açıdan anlamlı bir ilişki mevcuttur $\left(x^{2}=17.642 a, d f=8, p=0.024\right)$.

\subsection{Tartışma}

Tasarım öğelerinin önemli konularının içerisinde yer alan renk ve ışık çevreyi ayırt eden önemli öğelerdir. Renk ve ışı estetik endişelerin odak noktası olmasının yanında, renk dengesinin oluşturulması insan algısı yönünden önemlidir. Hiç kimse; estetikten yoksun, gelişigüzel düzenlenmiş, insan onurunu yok eden ve kültür yozlaşmalarının yer aldığı dayatmacı bir çevrede yaşamak zorunda değildir. Renk ve ışığın insanlar üzerindeki psikolojik etkisinden bahsedebilecek bu noktada, tasarımcının sağlam temellere oturttuğu çevrenin bilincine sahip olması ve tasarım öğelerini çok iyi irdeleyebilmesi gerekir.

Çalışmada, katılımcılar kentlerinde, yaşam alanlarında tercih edilen renklerin yaşayışları üzerine etki ettiğini belirtmiştir. Rengin günlük yaşamdaki rolünün varlığını kabul eden katılımcıların oranı da \%93'lere ulaşmaktadır. Bununla birlikte, katılımcıların entelektüel seviyeleri ve demografik verileri 
renk konusundaki seçimlerini de etkilemektedir. Berköz ve Küçükoğlu’na (1991) göre de, parıltının, doygunluğun, renk seçiminin uygun yapıldığı bir ortamda çalışmak ve yaşamak üretkenlik düzeyi ve ruh hali açısından da önemlidir.

Su yüzeyleri, kentsel alanlarda en dikkat çekici ve insanları çevresine toplama özelliğine sahip öğelerdir. Dolayısıyla bu alanların hem gündüz, hem de gece kullanımını ve dikkat çekiciliğinin devamını sağlamak önemlidir. Ancak, kentte su yüzey aydınlatmalarının yetersiz olduğu gözlemlenmiştir. Güçlüten'e (1993) göre havuzlar, göl ve yeşil alanlarda gece aydınlatması ile dekoratif aydınlatma yapılabilir. Bir havuz başındaki bitkinin suya vuran gölgesi ve hareketi insanı etkileyerek, ilgi ve heyecan uyandırır. Parklarda bulunan çitler, heykeller ve ilginç görüntüler de gece aydınlatılarak vurgulanmalıdır. Ağaçlar grup halinde aydınlatılabileceği gibi soliter tek bir ağacın aydınlatılması ile ilgi çekici bir görüntü sağlanabilir. Portela'ya (2007) göre; ışık, formların algısını ve bu formların içinde bulunduğu mekanların algılarını değiştirmektedir.

Rekreasyonel alanlardaki aydınlatmaya ilişkin de katılımcılardan görüş istenilmiş ve aydınlatmanın yetersiz olduğu belirtilmiştir. Bununla birlikte, bu rekreasyon alanlarındaki yetersiz aydınlatmanın kendilerini çok etkilediğini belirten katılımcıların oranı \%86'dır. Janssens'e (2000) göre psikolojik ruh hali ile performans arasında etkileşim mevcuttur.

Kentler, kimliklerini sadece gündüz değil, aynı zamanda iyi aydınlatma sistemlerinin kullanımı ile gece de yansıtabilmelidir (Sirel ve Sirel, 2005). Zaten ankette de Samsun kentinin gece görüntüsünün \%47 ile daha etkileyici değerlendirildiği ortaya çıkmıştır. Bireyin güvenlik duygusu temel düşünce olduğunda, dar alanı kaplayan düşük yükseklik ve dikey bir aydınlatma kalıbı en etkili yaklaşım olabilir. Doğru renk seçimi dış mekânın algılanmasını geliştirecektir (Güçlüten, 1993). Bunu destekler şekilde anket katılımcılarının \%63 gibi büyük bir kısmı da aydınlatmanın güvenli bir etki uyandırdığını belirtmiştir. Bununla birlikte, katılımcıların $\% 95,5^{\prime} \mathrm{i}$ hava karardıktan sonra yaya bölgelerini kullanmaktadır.

Donatılar, ışık ve renk kullanımı açısından değerlendirildiğinde Samsun kentinde mekanlar ritim ve hareketlilikten yoksundur. Bu da insanlar üzerinde monoton bir algı oluşturmaktadır. Ganslandt ve Hofmann'a (1992) göre; bir mekânda aydınlatmanın tasarımı esasen kullanıcı için görsel bir ortamın oluşturulması için önemlidir. Bununla birlikte, etkili ve amaca uygun ışık kaynağı, aydınlatma armatürü ve tekniğin uluslararası kriterlere göre projelendirilmesi sayesinde etkili bir peyzaj tasarımı ortaya çıkarılabilir (Güçlüten, 1993). Ayrıca, Steffy'ın (1990) bahsettiği gibi; ölçü, mekandaki aktiviteler, görsellik, döşemeler ve yüzey kaplaması aydınlatma tasarımını etkileyen başlıca unsurlardır.

\section{Sonuç ve Öneriler}

Samsun kentinde yapılan bu çalışma sonucunda görülmüştür ki; mevcut aydınlatma, ideal aydınlatma kriterlerini karşılayacak yeterlilikte değildir. Dış mekân aydınlatma yaklaşımında estetik değerlerden çok ihtiyacın karşılanması ön plana alınmıştır. Buna karşın ihtiyaçların da tam anlamıyla karşılandığı söylenemez. Anket sonucuna göre; kentteki aydınlatma \%65 oranında rastgele ve \%32 oranında ise yeterlidir. Bunun yanında, Samsun ili bir sahil kenti olduğundan deniz aydınlatması da yetersiz olarak değerlendirilmiştir. Anket sonuçlarına göre de; katılımcıların \%90'ı denizin sahilden aydınlatılmasını istemektedir. Bununla birlikte, dinlenme alanlarındaki ışıklandırma \%80 oranında yeterli, \%16 oranında ise çok iyidir.

Katılımcılar genel görüş olarak kentlerini gri bir kent olarak yorumlamaktadır. Bu algı kentin hem imajını hem de kentliye verdiği enerjiyi etkilemektedir. Ayrıca, katılımcılar kentindeki renk kullanımını da \%61 oranla rastgele olarak değerlendirmiştir. Bu algı ve imajı tersine çevirmek üzere; bina cepheleri bina rengi ile uyumlu ışıklarla aydınlatılabilir. Bina cephelerine renkli bitkilerin olduğu dikey bahçe uygulamaları gerçekleştirilebilir. Donatılar ve bitkiler spot ışılarla vurgulanabilir. Bitki kasaları renkli mevsimlik bitkiler ile daha renkli bir hale getirilebilir. Seçilen donatı, aydınlatma, döşeme ve bitki renkleri birbiri ile uyumlu hale getirilebilir. Donatı elemanlarının gece de etkin olmasını sağlamak için yerden aydınlatmalar ile vurgu tercih edilebilir. Gece karanlıkta kalan bitkilere ise renkli aydınlatma ile hareketlilik ve vurgu kazandırılabilir. Uçak'e (2000) göre renk ve doku değişimleri ile 
yüzey görünümünde farklılıklar sağlanmalı, böylece özellikle seviye farkının olduğu alanlarda yönlendirme ile verimli aydınlatma oluşturulmalıdır.

Bununla birlikte renk, çevre algısı üzerinde çarpıcı etkileri olan ve peyzaj mimarlığının kalite esaslardan birisidir. Bu yüzden çağdaş peyzaj mimarlı̆ı̆ın, rengin etkisini ilk tasarım aşamasından itibaren değerlendirmesi önemlidir (Zennaro, 2010). Açıklık, renk, doygunluk, renklerin bir yerde birleştirilmesi ve dağıtılması önemlidir (Stone, 2001; 2003). Bu nedenle de alanın çevresel analizi iyi yapılmalı, hedef kitleye dair özellikler, ihtiyaçlar ve gereksinimler değerlendirilmeli, çevreyle bütünleşik ve kullanıcılarda olumlu etki yaratabilecek tasarımlar gerçekleştirilmelidir (Cuttle, 2003; Demers, 2006; Petty, 2007; Portela, 2007).

Aydınlatmada da benzer durum geçerlidir. Yanlış aydınlatma, enerji kaybı ve estetik değerlerin tahribatı demektir. Bu açıdan hem güvenli hem estetik hem tasarruflu, hem de ihtiyacı karşılayan aydınlatmanın kullanılması önemlidir. Donatı elemanlarının tercihinde estetik ve ekonomi göz önünde bulundurulmalı, yaratacağı psikolojik etki de değerlendirilmelidir.

Tüm bunlarla birlikte kentsel aydınlatma çalışmalarında amaçlar ve sağlanacak faydalar net şekilde tespit edilmelidir. Kentlerde aydınlatma (Şerefhanoğlu, 2000); güvenlik, ulaşım rahatlığı, yer-yön bulma, sosyal aktiviteler, kentsel özel bölgelerin vurgulanması amaçlarıyla gerçekleştirilmelidir. Ayrıca, iyi bir aydınlatma sistemi için (Özkaya, 2000; Yıldırım, 2004); görme yetisinin artmasını sağlamasına, göz sağı̆ı̆ını korumasına, iş verimini artırmasına, ekonomik potansiyeli artırmasına, güvenliği sağlamasına, estetik duygulara hitap etmesine ve konforu sağlamasına özen gösterilmelidir.

\section{Teşekkür ve Bilgi Notu}

Bu makale, Ordu Üniversitesi Fen Bilimleri Enstitüsü Peyzaj Mimarlığı Ana Bilim Dalı'nda 2019 yııında tamamlanan ve "Peyzaj Mimarlığında Işık ve Renk Olgusunun Samsun Kenti Örnek Alanları Kapsamında İncelenmesi" adlı Yüksek Lisans tezinden üretilmiştir. Makalede, ulusal ve uluslararası araştırma ve yayın etiğine uyulmuştur. Yüksek lisans tezi, 2019 yılında tamamlandığı için etik kurul izni gerekmemiştir.

\section{Yazar Katkısı ve Çıkar Çatışması Beyan Bilgisi}

Makalede tüm yazarlar aynı oranda katkıda bulunmuştur Herhangi bir çıkar çatışması bulunmamaktadır.

\section{Kaynaklar}

Akıncı, E. ve Orhan, F. Ö. (2016). Sirkadiyen ritim uyku bozuklukları. Psikiyatride Güncel Yaklaşımlar, $8(2), 178-189$.

Arifoğlu, N. (1999). İstanbul Aydınlatma Master Plan Çalışmalarında Galata-Pera Taksim Bölgesi. Yüksek Lisans Tezi, Yıldız Teknik Üniversitesi, Fen Bilimleri Enstitüsü, İstanbul.

Başoğlu, Z. (2007). İlköğretim Çağındaki Çocukların Yön Bulma Davranışlarının Biçimlenmesinde iç Mekân Renk Uygulamalarının Etkileri. Sanatta Yeterlik Tezi, Hacettepe Üniversitesi, Sosyal Bilimler Enstitüsü.

Berköz, E. ve Küçükdoğu, M. (1991). Aydınlatma Ders Notları. İstanbul Teknik Üniversitesi, İstanbul.

Bostancı, S. H. (2002). Kentsel Tasarımda Aydınlatmanın Rolü. Yüksek Lisans Tezi, Mimar Sinan Güzel Sanatlar Üniversitesi, Fen Bilimleri Enstitüsü, İstanbul.

Christoffersen, J. (2011). The Importance of Light to Health and Well-being: 4th VELUX Daylight Symposium "Daylight in a Human Perspective", At Rolex Learning Center École Polytechnique Fédérale de Lausanne (EPFL), Lausanne, Switzerland.

Cuttle, C. (2003). Lighting by Design. Architectural Press, Oxford, 235 pp.

Danger, E. P. (1987). The Colour Handbook. Gower Publishing Company, Vermont, 687 pp. 
Dedeoğlu, i. (2006). Kentsel Yeşil Alanların Gece Kullanımında Dış Aydınlatmanın Önemi ve Yöntemi: Gülhane Parkı örneği. Yüksek Lisans Tezi, Bahçeşehir Üniversitesi, Fen Bilimleri Enstitüsü, İstanbul.

Demers, M. H. C. (2006). Assessing Light in Architecture: A Numerical Procedure for A Qualitative and Quantitative Analysis. International Lighting Conference, Associazione Italianadi Illuminazione (AIDI), Venice, Italy, 9-10 October.

Erzen, J. (2006). Çevre Estetiği. ODTÜ Yayıncılık, 155 s.

Fitoz, I.., Küçükerman, Ö. ve Esen, A. (2002). Aydınlatma tasarımı laboratuvarı. Yıldız Teknik Üniversitesi Mimarlık Fakültesi, E-Dergisi, 2 (2), s. 80-88.

Fontenelle, C. V. (2008). The Importance of Lighting to the Experience of Architecture - The Lighting Approach in Architectural Competitions. Germany, GR: Arkitekturskolan.

Ganslandt, R. ve Hofmann, H. (1992). Handbook of Lighting Design. Darmstadt: ERCO Edition, Germany, 289 pp.

Güçlüten, A. (1993). Peyzaj Tasarımında Yapay Aydınlatma Teknikleri. Yüksek Lisans Tezi, Ankara Üniversitesi, Fen Bilimleri Enstitüsü, Ankara.

Janssens, J. (2000). Påverkar Kontorets Färgsättning Produktiviteten. (Will the colours of an Office influence performance?) Aktuellt Må leri, 4, 24-27.

Jones, F. H. (1989). Architecturel Lighting Design. Crisppub, Los Altos, Cali, p.43-49.

Kandinsky, W. (1993). Sanatta Zihinsellik Üstüne, Yapı Kredi Yayınları, Çev. Tevfik Turan, İstanbul. Kelly. Journal of the Society of Architectural Historians, 66(2), 194-219.

Kolb, H. (2003). How The Retina Works: Much of The Construction of an Image Takes Place In The Retina Itself Through The Use of Specialized Neural Circuits. American Scientist, 91(1), 28-35.

Kueller, R. ve Mikellides, B. (1993). Simulated Studies of Color, Arousal, and Comfort. In Environmental Simulation, Springer, Boston, MA, 163-190.

Küller, R. ve Mikellides, B. (1993). Simulated Studies of Color, Arousal, and Comfort. In Environmental Simulation. Research and Policy Issue, R.W. Marans and D. Stokols (Eds.), pp. 163-190 (New York: Plenum Press).

Kwallek, N., Lewis, C. M., Lin-Hsiao, J. W. D. ve Woodson, H. (1996). Effects of Nine Monochromatic Office Interior Colors on Clerical Tasks and Worker Mood. Color Research \& Application, 21(6), 448-458.

Norberg-Schulz, C. (1984). Genius Loci, Towards a Phenomenolgy of Architecture. Newyork: Rizzoli.

Onuk, N. T. (2008). Kentsel Dış Mekânların Aydınlatılması Kapsamında Işık Kirliliğinin İrdelenmesi. Yüksek Lisans Tezi, İstanbul Teknik Üniversitesi, Fen Bilimleri Enstitüsü, İstanbul.

Özdemir, T. (2005). Tasarımda renk seçimini etkileyen kriterler. Çukurova Üniversitesi Sosyal Bilimler Enstitüsü Dergisi, 14(2), 391-401.

Özkaya, M. (2000). Aydınlatma Tekniği. Birsen Yayınevi, İstanbul, 499 s.

Petty, M. M. (2007). Illuminating The Glass Box: The lighting designs of Richard.

Phillips, D. (2000). Lighting Modern Buildings, Architectural Press, Oxford, 100 pp.

Portela, C. (2007). Light in Architecture. Starlight Conference, April, La Palma, Canary Islands.

Radwan, A. (2015). Color in architecture is it just an aesthetic valueor a truehuman need. International Journal of Engineering Research \& Technology, 4(12), 523-533.

Rasmussen, S. E. (1964). Experiencing Architecture (Vol. 2). MIT press. 
Sirel, Ş. (1997). Müzelerde ve Bürolarda Aydınlatma. Yapı Fiziği Uzmanlık Enstitüsü Yayını, Kitapçık No:8, s. 13, İstanbul.

Sirel, A. ve Sirel, Ü. (2005). Kamusal Dış Mekânlarının Tasarımında Aydınlatma Boyutu: Edirne'de Hürriyet Meydanı (parkı) ile illgili Bir Araştırma TMMOB Elektrik Mühendisleri Odası. III. Ulusal Aydinlatma Sempozyumu. 23-25 Kasım 2005 Ankara.

Steffy, G. (2002). Architectural Lighting Design. John Wiley \& Sons, New York.

Stone, N. J. (2001). Designing effective study environments. Journal of Environmental Psychology, 21, 179-190.

Stone, N. J. (2003). Environmental view and color for a simulated telemarketing task. Journal of Environmental Psychology, 23, 63-78.

Şerefhanoğlu, S. M. (2003). Aydınlatma Tasarımında Mimarın ve Elektrik Mühendisinin Rolü. II. Ulusal Aydınlatma Sempozyumu, 8-10 Ekim, Diyarbakır.

Uçak, i. (2000). Meydan Mekanlarını Oluşturan Peyzaj Ögeleri: Ortaköy Meydanı ve Bakırköy Özgürlük Meydanı Üzerine Bir İnceleme. Yüksek Lisans Tezi, İstanbul Teknik Üniversitesi, Fen Bilimleri Enstitüsü, İstanbul.

Ünver, R. (2001). İç mekandaki gölgelerin düzenlenmesi. Tasarım Dergisi, (110), 112- 115.

Yıldııım, B. (2004). Konut iç Mekân Tasarımında Doğal Ve Yapay Aydınlatma Illkeleri. Yüksek Lisans Tezi, Hacettepe Üniversitesi, Sosyal Bilimler Enstitüsü, Ankara.

Zennaro, P. (2010). Colour and Light in Architecture. Knemesi, Verona, Italy, 540 pp. 